\author{
Monika Krajewska \\ Uniwersytet Mikołaja Kopernika w Toruniu \\ monika.krajewska@umk.pl
}

\title{
AUTOR JAKO DRUGI TŁUMACZ
}

DOI: http://dx.doi.org/10.12775/RP.2017.020

Zarys treści: Parafrazując tytuł tekstu Anny Legeżyńskiej „Tłumacz jako drugi autor” (1999: 20-30), w niniejszym artykule zwracam uwagę na rolę kontaktu z autorem w procesie tworzenia przekładu. Konsultowanie z twórcą oryginału niektórych rozwiązań translatorskich redukuje wątpliwości interpretacyjne widziane z pozycji tłumacza, autorowi zaś daje możliwość zobaczenia swojego tekstu z perspektywy drugiego języka.

Słowa kluczowe: kontakt z autorem, proces przekładu, wątpliwości interpretacyjne, Konstantin Arbienin, „Bezsenne bajki” („Сказки на засыпку”), Pieriewodka

Aвтопортрет 1987 года...

В общем-то, я почти не изменился*.

W ramach prezentowanego artykułu w kilku słowach przedstawię pewną tłumaczeniową przygodę, której bohaterem jest Konstantin Arbienin, pochodzący z Petersburga wszechstronnie utalentowany artysta - poeta, prozaik, muzyk, aktor, a także rysownik. W latach 80 . XX wieku - według jego słów - rysowanie znajdowało się na równi z pisaniem, choć potem pisanie zwyciężyło. Obok zamieszczam autoportret pisarza, który

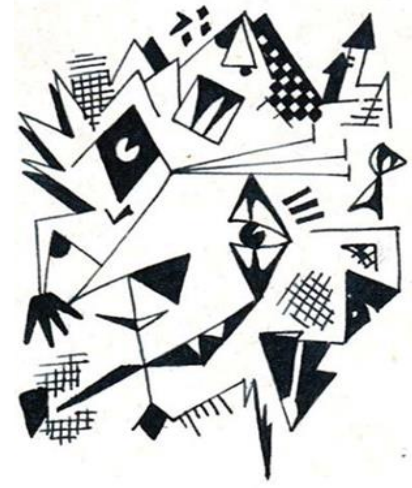
przekonuje, że jego wizerunek właściwie niewiele się zmienił.

* Źródło: https://www.facebook.com/photo.php?fbid=862893297082952\&set=a. 65893640 4145310.1073741827.100000868684065\&type=3\&theater (dostęp: 16 czerwca 2016 r.). 
Konstantin Arbienin to człowiek, którego - używając słów Andrzeja Pawelca - chciałabym „przyswoić polszczyźnie [...], sprawić, żeby przemówił po polsku” (Pawelec 2013: 13). Arbienin nie tylko przemówił, ale zdążył już nawet „zaśpiewać” po polsku głosem Małgosi Kudlik (m.in. finalistki X edycji konkursu „Pamiętajmy o Osieckiej”), która przyjęła zaproszenie do wzięcia udziału w jednym z kwartirników organizowanych przez Pieriewodkę, sekcję translatoryczną Koła Naukowego Rosjoznawców UMK ${ }^{1}$.

Wspomniane „przemówienie po polsku” w tym kontekście jest traktowane dosłownie, gdyż zawarte poniżej uwagi będą dotyczyć przygotowania audiobooka. Projekt ten obejmuje 31 utworów petersburskiego pisarza - od bardzo krótkich (kilkuwersowych) do nieco dłuższych (półtorastronicowych). Etap przekładowy został zrealizowany w ramach pracy członków wspomnianej sekcji translatorycznej ${ }^{2}$, etap muzyczny - przez zaprzyjaźnionych muzyków (Dominik Kisiel, Michał „Sasin” Sasinowski, Bartosz Wojdak, Kacper Dąbrowski; głosu i tym razem użyczyła Małgosia Kudlik), etap graficzny $^{3}$ zaś - przez Annę Kraińską i Wiktorię Łukasiewicz.

Do listy osób odpowiedzialnych za ostateczny kształt tekstów docelowych należy też włączyć samego autora, będącego nie tylko sprawcą wziętych na warsztat tekstów, ale też w pewnym stopniu współtwórcą tłumaczenia. W jego utworach - choć krótkich - nie brakuje intertekstualnych nawiązań, gier słownych i innych przekładowych trudności; można by powiedzieć - w słowach niewielu treści wiele. Zatem i pytań do autora całkiem dużo. Początkowo były one nieśmiałe, żeby nie urazić brakiem zrozumienia, nieodczytaniem założonej tezy, szybko jednak się okazało, że autor $\mathrm{z}$ zaciekawieniem obserwuje swoje utwory zakorzeniające się w innym gruncie językowym. W jednej z rozmów (26.11.2015) odpowiada: Пuuu, спрашивай - мне самому это интересно! (Pisz, pytaj, sam jestem ciekawy), skorzystałam więc z tego zaproszenia, zapraszając jednocześnie Arbienina do współpracy.

Wpływ autora na tekst przekładu można rozpatrywać na dwóch poziomach. Pierwszy dotyczy inicjalnego etapu procesu tłumaczenia, a mianowicie interpretacji tekstu. Dzięki kontaktowi z pisarzem można uniknąć niepożą-

1 Utwór „Romans” (słowa: Konstantin Arbienin, tłum. Monika Krajewska, aranżacja muzyczna Arek Krawiel i Michał „Sasin” Sasinowski) w kwartirnikowym wydaniu został udostępniony na kanale YouTube: https://www.youtube.com/watch?v=tyyJ68_URbc (dostęp: 16 czerwca 2016 r.). Więcej na temat działalności Pieriewodki, w tym o spotkaniach muzycznych zob. Krajewska 2016: 217-230.

2 Wykaz wszystkich utworów wraz z nazwiskami tłumaczy znajduje się w bibliografii.

3 Strona internetowa w przygotowaniu. 
danego przez oryginał odczytania, a w konsekwencji - wyboru nieadekwatnego wariantu, co warto zilustrować przykładem.

Już na samym początku, w „Bajce wstępnej”, pojawił się znak zapytania. Mowa jest tam o porzuconych, bezdomnych bajkach: zimą tułały się po mieście, niektóre z nich znajdowały schronienie w piwnicach, inne - замерзали

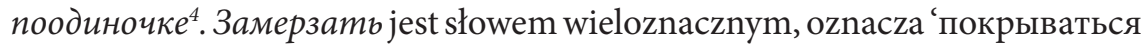
льдом' ('pokrywać się lodem', o zbiornikach wodnych), 'превращаться в лёд' ('zmieniać się w lód'), 'погибать от мороза' ('ginąć, umierać z zimna, wychłodzenia') i wreszcie w stylu potocznym 'сильно зябнуть от мороза' ('ziębnąć, marznąc'). Choć w polskim odpowiedniku - słowie zamarzać można odnaleźć wszystkie powyższe znaczenia, to jednak pewne konstrukcje wywołują odmienne asocjacje. O ile powiedzenie ręce mi zamarzają, zamarzam (w czasie teraźniejszym) powiążemy z ziębnięciem, o tyle już czas przeszły, np. bajki zamarzły raczej odbierzemy jako 'umarły w wyniku działania mrozu" (por. Pierwsze ofiary mrozu. Już cztery osoby zamarzly w tym roku $w$ Warszawie i okolicy...). Może te dywagacje osobom postronnym wydadzą się błahe, jednak to tak naprawdę „być albo nie być” owych bajek. A jeszcze gorzej, jeśli „być” w oryginale, a "nie być” w przekładzie. Absolutnie nie chciałoby się uśmiercać bezdomnych bajek tylko i wyłącznie z powodu przekroczenia językowej granicy. Tłumacz zostałby okrzyknięty nie tylko zdrajcą, ale i mordercą.

W tym przypadku, dzięki kontaktowi z autorem, który pisze Hem, я не имел в виду, что они умирали. Скорее очень мёрзли (26.11.2015) ('nie, nie miałem na myśli, że umierały, raczej, że bardzo marzły'), marznące w samotności bajeczki nie powtórzyły losu andersenowskiej dziewczynki z zapałkami.

Wieloznaczność nie tylko w powyższym przykładzie zrodziła pytanie skierowane do autora i choć jako tłumacz zdaję sobie sprawę, że ideałem byłoby przeniesienie do przekładu możliwości wielopłaszczyznowej interpretacji, to mam też świadomość, że nie zawsze jest to osiągalne (lub - co trzeba zaznaczyć - nie zawsze tłumacz potrafi znaleźć takie rozwiązanie). Gdy więc zrezygnowany wybiera jednoznaczność, lepiej, by wiedział, które ze znaczeń wyeksponować w tekście docelowym. W utworze „Druga młodość” serwisant RTV Telesfor Palsekamowicz Pudełko pod koniec zmiany idzie naprawiać telewizor do mieszkania dwóch staruszek, w wieku po 180 lat każda. Adres: Затрапезный переулок. Rodzi się pytanie, co kryje się pod taką właśnie nazwą. Czy jest ona po prostu zwykłym toponimem (urbanonimem), elementem na mapie? Jak w przypadku moskiewskiej ulicy Сеченовский переулок, która

\footnotetext{
4 Fragmenty bajek cytowane za Арбенин 2012: online.
} 
powstała w XVIII wieku, właśnie pod nazwą Затрапезный, prawdopodobnie od nazwiska właściciela domu (Энцииллопедия Dslov: online).

Warto cofnąć się do 1707 roku, kiedy to Piotr I założył w Moskwie fabrykę płótna, która z racji tego, że nie przynosiła spodziewanych zysków, w roku 1718 została przekazana w prywatne ręce (Иван Павлович Тамес: online). Właścicielem okazał się Iwan Pawłowicz (Иван Павлович Тамес: online), a jednym ze wspólników - jarosławski kupiec Maksim Zatrapieznyj wraz ze swoimi czterema synami (3ampaneзныe: online). Zatrapieznyj (w niektórych źródłach Zatrapieznow), widząc dochodowość interesu, w 1722 roku złożył podanie (wraz z Tomesem) o zgodę na otwarcie fabryki płótna w rodzinnym Jarosławiu. W drugiej połowie lat 20. XVIII wieku w dokumentach pojawia się już imię syna - Iwana Zatrapieznego, za którego rządów jarosławska manufaktura liczyła około 6000 pracowników. Produkowano w niej jedwabne obrusy i serwetki jakością nieustępujące holenderskim (Ярославская большая мануфактура: online), ale też tanie tkaniny, w tym na dużą skalę drelich, który - i tu dochodzimy do sedna sprawy - od nazwiska właścicieli zyskał nazwę zatrapiez (Ярославская большая мануфактура: online). W związku z tym, gdy zajrzymy do słowni$\mathrm{ka}$, otrzymamy informację, że затрапезный to 'zgrzebny, (zrobiony) z grubej taniej tkaniny', co z kolei stało się podłożem do kolejnej znaczeniowej odsłony - 'powszedni, codzienny' (платье 'ubranie', вид 'wygląd'; WSRP1: 379). To jednak nie wyczerpuje możliwych odczytań, należy bowiem przytoczyć jeszcze słowo mрапеза, oznaczające 'stół, posiłek, jadło' (WSRP2: 599), które wraz z przyimkiem stanowi źródłosłów przymiotnika затрапезный (książ., przest.)., a więc 'mający miejsce przy stole, biesiadny' (WSRP1: 379). Okazuje się więc, że mieszkanie naszych staruszek mieści się przy ulicy, której nazwa jest nośnikiem wielu znaczeń, wszystkich niestety w przekładzie oddać się nie da, zatem tłumacz musi rozstrzygnąć, które z nich jest najważniejsze. Również i tu pomógł sam autor, odpowiadając (31.07.2015), że затрапезный w tym kontekście to raczej 'zwykły, codzienny'. Takie rozumienie pięknie współgra z treścią bajki, owe staruszki (nie tylko ze względu na bardzo sędziwy wiek) są niezwykłymi osobami: w ramach zapłaty za naprawę niezwykłego telewizora (egzemplarz zabytkowy, takich już nie uświadczysz, jak z bajki o srebrnym talerzyku i soczystym jabłuszku, które, toczac się, pokazywało obraz świata) wręczają Telesforowi buteleczkę niezwykłego alkoholu: To, kochaniutki, nie taki sobie zwykty alkohol, to odmładzająca naleweczka. Pij na zdrowie! Niezwykli ludzi i niezwykłe sytuacje w mieszkaniu przy zwykłej ulicy, chciałoby się powiedzieć $w s z a-$ rej rzeczywistości. Epitet ten stał się również ekwiwalentem przekładowym w tłumaczeniu pojawiła się bowiem ulica Szara, która w pewnym sensie odzwierciedla myśl autora, ponadto jest spotykanym elementem przestrzeni 
miejskiej (np. ulica Szara w Gdańsku, улица Серая w Grodnie, улица Серая w Brześciu).

Kolejne elementy przestrzeni miejskiej to Mojkin i Fontankin - nazwiska bohaterów utworu o tym samym tytule, wywodzące się od hydronimów nazw petersburskich rzek, Mojki i Fontanki. Nasi bohaterowie są czarodziejami (jeden dobrym, drugi złym), którzy - chcąc zapanować nad bałaganem wynikającym z przychodzenia ludzi pod nieodpowiedni adres (wybierający się do dobrego często trafiali do złego i na odwrót), postanowili zmienić nazwiska i miejsca zamieszkania. Fontankin przybrał nazwisko Фонтанов і zamieszkał w Peterhofie, Mojkin zaś nazywał się od tej pory Помойкин, a na miejsce życia wybrał Kołpino.

O ile pierwszą nazwę (Peterhof) przynajmniej część polskich odbiorców umiejscowi na mapie (a jeśli tak, to zapewne wywoła ona przy okazji pozytywne konotacje - słynny zespół pałacowo-ogrodowy), o tyle Kołpino polskiemu czytelnikowi raczej z niczym się nie skojarzy. Istnieje ryzyko, że może też nie skojarzyć się z niczym i odbiorcom oryginału mieszkającym poza Petersburgiem czy obwodem leningradzkim. Nowe nazwisko złego czarodzieja - Помойкин - to oczywiste nawiązanie do słowa помойкa, które oznacza 'śmietnik' (pot.), 'dół na pomyje, odpadki, śmieci' (WSRP2: 150). Można zadać sobie pytanie, czy Kołpino ma z tym coś wspólnego. Na pytanie to należy odpowiedzieć twierdząco, a zatem Peterfhof wywołuje asocjacje z fontannami, Kołpino - m.in. z wielkim wysypiskiem śmieci, dokładnie zaś z poligonem „Krasnyj bor”, na którym są składowane odpady toksyczne. Zarówno ukrytą w nazwisku Fontanow rzekę Fontankę (notabene pochodzącą właśnie od słowa fontanna), jak i późniejsze fontanny w Peterhofie daje się przetransponować na grunt języka polskiego. Z drugim nazwiskiem jest już większy problem, choć i tu zaproponowany ekwiwalent - Pomyjkin - nawiązuje do nazwy rzeki i jednocześnie wyrazu pospolitego (tu: pomyje 'brudna woda po myciu naczyń, z resztkami jedzenia'). Choć mamy do czynienia $\mathrm{z}$ nieco innym znaczeniem, to mieści się ono w zakresie wytyczonym przez swoistą antonimiczność oryginału, a nawet wydaje się tę antonimię bardziej podkreślać: fontanna vs pomyje. Jednak z drugiej strony zmiana podstawy z leksemu śmietnik na pomyje oddala ewentualne skojarzenie Kołpina z wysypiskiem śmieci. Takie skojarzenie u mieszkańców Gdańska (których prywatnie reprezentuję) natychmiast powstałoby na hasło „Szadółki”, lecz substytucja polegająca na wymianie jednej nazwy lokalnej na inną w tym konkretnym kontekście nie miałaby większego sensu, ponieważ:

1) jasność odbioru zostałaby zawężona do stosunkowo niewielkiego obszaru (tu: Gdańska i okolic); 
2) akcja utworu opuściłaby swoje pierwotne granice, co z kolei przeczyłoby przyjętej strategii zachowania w przekładzie obcości, ewentualnie jej neutralizowania (jak w przypadku wspomnianej ulicy Szarej).

W związku z powyższym w tłumaczeniu zastosowano krótkie komentarze wewnątrztekstowe: Zdawało się, że teraz już zapanuje porzadek, gdyż ludzie zapamiętali, że Fontanow mieszka w Peterhofie, gdzie piękne fontanny $w$ carskim ogrodzie, a Pomyjkin to ten $z$ Kolpina, gdzie wysypiska śmieci. Ze względu na fakt opracowywania przekładu z myślą o audiobooku możliwe były jedynie tego typu parateksty ${ }^{5}$.

W utworach, w których - jak już wspomniałam - niemało jest gier słownych, tłumacz, czyli osoba starająca się wychwycić wszystko i możliwie dużo $\mathrm{z}$ tego oddać $\mathrm{w}$ przekładzie, niekiedy widzi zbyt wiele - wszędzie dopatruje się pułapki, kalamburu, gry z czytelnikiem. I tu kontakt $\mathrm{z}$ autorem jest równie ważny - dzięki niemu często udaje się uniknąć zbyt daleko idących interpretacji. W cytowanej wcześniej „Bajce wstępnej” pojawia się fraza: „Так сказал сказочник”, która swą formą przypomina: „Так говорил Заратустра”. Oczywiście nie chodzi o jakieś współbrzmienia treści, a jedynie o postać samego stwierdzenia. Wyjaśnienie, czy rzeczywiście w oryginale wykorzystano wspomniany schemat tytułu, jest o tyle ważne, że w języku polskim bardzo łatwo przechylić szalę z neutralnego „Tak powiedział bajarz” na nacechowane „Tako rzecze bajarz" (ew. „tako rzekł bajarz”)'. Mało tego, pisarz zapytany o wage powtórzonego rdzenia (так сказал сказочник) odpowiedział, że to przypadkowe, nie brzmi dobrze i najlepiej byłoby odejść od tego w oryginale. Zatem korespondencja rzutuje nie tylko na wybory translatorskie, ale może mieć też wpływ na ponowne wybory autorskie ${ }^{7}$.

${ }^{5}$ W nawiązaniu do formy audiobooka warto powiedzieć o swego rodzaju cezurze, jaką jest zapis wersji lektorskiej - do czasu nagrania trwa bowiem nieustanna korekta. Jak zauważa Carlos Marrodán Casas, „chyba wszyscy tłumacze mają to do siebie, że żadnego z przetłumaczonych zdań nie traktują jako ostatecznego. To jest nasza zawodowa obsesja i fobia. Przy każdym przekładzie w końcu trzeba jednak postawić kropkę, podjąć decyzję, że praca jest skończona. Ale nigdy przynajmniej w moim wypadku - nie obywa się to bez wątpliwości i gdyby nie bezpardonowe ponaglenia wydawców, pewnie nad wszystkim pracowałbym dużo dłużej" (Marrodán Casas, Zaleska 2015: 27). W przypadku pracy nad naszym audiobookiem ową kropką nie są ponaglenia wydawców, a nagranie, które wyznacza zamknięcie translacyjnego etapu.

${ }^{6}$ Por. F. Nietzsche, Tak mówił Zaratustra: ksiażka dla wszystkich i dla nikogo, tłum. G. Sowiński, Kraków 2005; F. Nietzsche, Tako Rzecze Zaratustra, tłum. W. Berent, Toruń 1922; F. Nietzsche, Tak mówił Zaratustra [książka dla wszystkich i dla nikogo], cz. 1, tłum. M. Cumft i St. Pieńkowski, Warszawa 1901.

${ }^{7}$ Kilka lat temu miałam przyjemność analizowania korespondencji między Stanisławem Lemem i jego tłumaczem Konstantinem Duszenką. W artykule „Cieplica to wystygła zimni- 
Odnośnie do wyborów autorskich warto też przybliżyć tajemnicę powstania jednego obrazu, wykorzystanego w utworze „Złodziej”. W tej bajce pojawiają się małe sfinksy karmione przez swojego opiekuna свиниовым молоком, czyli 'ołowianym mlekiem'. Powstaje pytanie, co jest tu ważne: czy rzeczywiście ołowiane mleko (może przy okazji problem karmienia niemowląt krowim mlekiem, które jest zanieczyszczone ołowiem?, zob. Kowalczyk) czy brzmienie bez znaczeniowego zaplecza (сфинксы - свинцовое молоко), czy - najgorszy dla tłumacza wariant - jedno i drugie? (A jak widać i słychać, wyraz ołów w języku polskim nie ma nic wspólnego z wyrazem sfinks). Okazało się, że ani jedno, ani drugie, gdyż свинцовое молоко to po prostu efekt snu: (7.07.2015) Вообще я не думал о схожести сфинксов и свинца, свинцовое молоко я увидел во сне, а потом уже оно вписалось в эту сказку (W ogóle nie myślałem o podobieństwie słów, ołowiane mleko zobaczyłem we śnie, a potem już wpisało się ono $\mathrm{w}$ tę bajkę) $)^{9}$. Zanim pisarz opowiedział o zrodzonym ze snu ołowianym mleku, został poinformowany o braku możliwości przeniesienia do przekładu leksemu ołów wraz ze znaczeniem i fonetycznym podobieństwem do wyrazu sfinks oraz otrzymał kilka propozycji przekładowych, na których mogłaby być oparta gra słów (gdyby skład mleka - ołów nie miał decydującego znaczenia). Wśród owych propozycji znalazły się m.in.: swingowy, sfingowany oraz sfinksowaty (tj. 'tajemniczy, zagadkowy'). W tym miejscu dochodzimy do momentu, kiedy autor, przyglądając się swojemu tekstowi (fragmentowi tekstu) odbitemu w lustrze innego języka i wskazując na konkretny wariant, wpływa na kształt przekładu, staje się w jakimś stopniu jego współtwórcą. A zatem - w nawiązaniu do tytułu niniejszego tekstu - autor staje się drugim tłumaczem. Co prawda wybiera z zazwyczaj ograniczonego zbioru możliwości, niemniej to właśnie on stawia przysłowiową kropkę nad „i”. Reakcja pisarza (7.07.2015): «Сфинксоватое молоко» - отлично, то что

ca”... pisałam m.in. o wpływie uwag tłumacza na losy oryginału w kolejnych wydaniach (zob. Krajewska 2010).

${ }^{8}$ Por. „Dla niemowląt główne źródło ołowiu stanowi mleko krowie, z którego jest on szczególnie łatwo przyswajalny” (Kowalczyk: online). Zagadnienia ekologiczne nie są obce tłumaczonemu cyklowi bajek, dlatego też i ołowiane mleko w pierwszej chwili można by przypisać do tej kategorii.

${ }_{9}$ Warto w tym miejscu przytoczyć fragment innego utworu, który koresponduje z doświadczeniem „widzenia snów”: „Taka jest natura tworzenia: nie da się wymyślić tego, czego na świecie nie ma. Bajarze wiedzą o tym najlepiej i właśnie dlatego nawet nie próbują fantazjować. Stwierdzają tylko suche fakty. Jednak trochę inaczej pracuje u nich narząd wzroku - jednym okiem widzą to, co pozostali ludzie, a drugim to - czego zwykli ludzie nie zauważają. Poza tym bajarze widzą sny nie tylko nocą. Dlatego często mają problemy z oczami, a i z głową niekiedy też" (tłum. М.К.), (Арбенин 2014: online). 
надо! [...] свиниовое молоко [...] - то есть это такое несуществующее на самом деле молоко, и слово «загадочное» очень даже подходит! (Sfinksowate mleko - świetnie, to, co potrzeba! Ołowiane mleko - w rzeczy samej nieistniejące mleko, zatem słowo „zagadkowe” bardzo tu pasuje).

Aktywny udział pisarza w procesie tego konkretnego przekładu odbił się też na ostatecznej wersji tytułu. Cykl bajek w języku rosyjskim nosi nazwę „Сказки на засыпку”. Tu akurat mamy do czynienia z grą słów założoną przez autora. Druga część tytułu odnosi się bowiem i do słowa 3acbınamb, dk. заснуть 'zasypiać (zasnąć)', i do засыпаться (провалиться) на экзамене 'sypnąć się na egzaminie'. Tytuł oryginału wykorzystuje konstrukcję вопросы на засыпкy, czyli pytania, na których można się sypnąć, a w konsekwencji oblać egzamin. Można by oddać go w postaci podchwytliwe bajki (wykorzystując wyrażenie podchwytliwe pytania), ale wówczas zgubimy grę słów i odwołanie do zasypiania; można by też wykorzystać parę zasypiać i zasypywać (zasypani pytaniami, problemami) - jednak to rozwiązanie niesie z kolei niebezpieczeństwo uczucia przytłoczenia (zasypani bajkami 'zmęczeni nimi'). Spośród kilku propozycji pisarz szczególną uwagę zwrócił na dwie: porzucone bajki (które nawiązywały do treści „Bajki wstępnej”) i bezsenne bajki. Ostatecznie został wybrany drugi tytuł (25.11.2015): „Бессонные сказки” - мне нравится, и по смыслу, и по звучанию („Bezsenne bajki” podobają mi się i pod względem brzmienia, i pod względem znaczenia). Bezsenne - słuchane przed snem, z tego snu wybudzają, każą zastanowić się na poruszanymi tematami, nad sobą - kim jestem? - dzięki temu są też bezcenne.

Zasugerowałam pisarzowi napisanie bajki, która szuka drogi do innego języka. Niech ten artykuł będzie jej namiastką.

\section{Literatura}

\section{Źródła:}

Арбенин, К., 2002, Сказки на засыпку, http://1000plastinok.net/Konstantin_Arbenin/Skazki_na_zasypku_2002/(dostęp: 16 czerwca 2016 r.).

\section{Wykaz utworów i tłumaczy:}

1. Предисловная сказка

2. Ослиная репка

3. Радиолюбитель

4. Губы императора
Monika Krajewska

Monika Kostrzewa

Paulina Kozicka

Dominika Biedulska 
5. Дракон

6. Везучий банкир

7. Bop

8. Привидение

9. Мойкин и Фонтанкин

10. Философский гриб

11. Очки

12. Пустая коробка

13. Лампочки

14. Стрелочник

15. Фальшивые ноть

16. Фотограф

17. Букварь и Азбука

18. Пара к nаре

19. Cnор

20. Люди и звёздь

21. Тридиать третий богатырь

22. Самобранка

23. Самая страшная сказка

24. Свои среди тараканов

25. Рабы mapы

26. Две столицы

27. Ледяной город

28. Бабушка Жара

29. Дело о носовых платках

30. Руководство по эксплуатации

31. Вторая молодость
Monika Kostrzewa

Dominika Biedulska

Andżelika Rutkowska

Katarzyna Jóźwiak

Dominika Biedulska

Aleksandra Biniek

Anna Kosznik

Monika Krajewska

Monika Krajewska

Paulina Kozicka

Katarzyna Jóźwiak

Monika Krajewska

Katarzyna Jóźwiak

Katarzyna Jóźwiak

Angelika Pawlaczyk

Anna Mączyńska

Marta Gaszak

Danuta Rosentreter

Paulina Kozicka

Alina Tyszkiewicz

Danuta Rosentreter

Elżbieta Buczyńska

Angelika Pawlaczyk

Aleksandra Biniek

Alina Tyszkiewicz

Monika Krajewska

Monika Krajewska

Арбенин, К., 2014, „Предисловие”, [w:] Король жил в подвале и другие сказочные истории, Санкт-Петербург, http://knigi-tut.net/read/korol-jil-v-podvale-i-drugie-skazochnyie-istorii/1 (dostęp: 16 czerwca 2016 r.).

\section{Literatura przedmiotowa:}

Kowalczyk, Z., Zagrożenie środowiska metalami ciężkimi, http://www.profesor.pl/mat/na7/na7_z_kowalczyk_030729_1.php?id_m=5640 (dostęp: 16 czerwca 2016 r.). 
Krajewska, M., 2010, „«Cieplica to wystygła zimnica». Wizerunek tłumacza na tle korespondencji z pisarzem", [w:] Lem i tłumacze, E. Skibińska, J. Rzeszotnik (red.), Kraków, s. 117-135.

Krajewska, M., 2016, Pieriewodka - dydaktyka po godzinach, „Rocznik Przekładoznawczy. Studia nad teorią, praktyką i dydaktyką przekładu”, E. Kościałkowska-Okońska, L. Zieliński (red.), nr 11, s. 217-230.

Legeżyńska, A., 1999, „Tłumacz jako «drugi autor»” (fragment rozdziału „Autor - Tłumacz - Przekład), [w:] eadem, Tłumacz i jego kompetencje autorskie, Warszawa, wydanie drugie rozszerzone, s. 20-30; zob. też: eadem, 1997, „Tłumacz jako drugi autor - dziş”, [w:] Przekład literacki. Teoria - Historia - Wspótczesność, A. Nowicka-Jeżowa, D. Knysz-Tomaszewska (red.), Warszawa, s. 40-50.

Marrodán Casas, C., Zaleska, Z., 2015, „Tłumacz siedzi we mnie głęboko”, [w:] Z. Zaleska, Przejęzyczenie. Rozmowy o przekładzie, Wołowiec, s. 7-31.

Pawelec, A., 2013, „Ocalone w komentarzu do tłumaczenia”, [w:] Wkład $w$ przekład. Materiaty pokonferencyjne V, VI i VII Studenckich Warsztatów Tłumaczeniowych, Kraków 2010-2012, A. Filipek, M. Osiecka (red.), Kraków, s. 11-14.

WSRP, Wielki słownik rosyjsko-polski, 1999 (wyd. VI), A. Mirowicz, I. Dulewiczowa, I. Grek-Pabisowa i in. (red.), Warszawa (t. 1 i 2 ).

3атрапезные, https://ru.wikipedia.org/wiki/Затрапезные (dostęp: 16 czerwca 2016 r.).

„Иван Павлович Тамес”, [w:] Ярославль (Персоналии), http://www.moi-jaroslavl.ru/jar-litsn/kuptsi/176-ivan-tames.html (dostęp: 16 czerwca 2016 r.).

„Максим Семенович Затрапезнов”, [w:] Ярославль (Персоналии), http:// www.moi-jaroslavl.ru/jar-litsn/kuptsi/177-maksim-zatrapeznov.html (dostęp: 16 czerwca 2016 r.).

Энициклопедия Dslov.ru, http://dslov.ru/slov/162.htm (dostęp: 16 czerwca 2016 r.).

„Ярославская большая мануфактура”, [w:] Ярославль (Странищы истории), http://www.moi-jaroslavl.ru/straniziistorii/179-ja-b-m.html (dostęp: 16 czerwca 2016 r.). 


\section{The author as the second translator}

Summary

Paraphrasing the title of Anna Legeżyńska's text "The translator as the second author" (1999: 20-30), this paper focuses on the role of contact with the author in the translation process. Discussions with the author on certain translation solutions reduce interpretative doubts as seen from the perspective of the translator, while the author is given an opportunity to see his or her text from the perspective of another language. In this text I am referring and quoting selected examples that were included in the letters exchanged with Konstantin Arbienin, the author of "Sleepless Stories" (Сказки на засыпку) whose translation has become the basis for making an audiobook. The project was launched within the activity framework of ,Perevodka, a translation section of the Research Association of the Department of Russian Studies at the NCU in cooperation with our friends musicians and graphic artists.

Keywords: contact with the author, translation process, interpretative doubts, Konstantin Arbienin, “Sleepless Stories” (“Сказки на засыпку”), Perevodka 
